\title{
C-Met Inhibitor AMG 208
}

National Cancer Institute

\section{Source}

National Cancer Institute. c-Met Inhibitor AMG 208. NCI Thesaurus. Code C82677.

A selective small-molecule inhibitor of the proto-oncogene c-Met with potential

antineoplastic activity. c-Met inhibitor AMG 208 inhibits the lig and-dependent and lig andindependent activation of c-Met, inhibiting its tyrosine kinase activity, which may result in cell growth inhibition in tumors that overexpress c-Met. C-Met encodes the hepatocyte growth factor receptor tyrosine kinase, plays an important role in epithelial cell proliferation and has been shown to be overexpressed in a variety of cancers. 